\title{
Urinary and Serum N-acetyl B-Glucosaminidase as Biomarkers of Albuminuria in Patients with Type 2 Diabetes
}

\author{
Ahmed Mahdi Daham', Raid AL-Timimi ${ }^{2}$ \\ ${ }^{1}$ Post Graduate, ${ }^{2}$ Assist. Prof., Department of Chemistry and Biochemistry, \\ College of Medicine, AL-Nahrain University, Iraq
}

\begin{abstract}
Background: Diabetic nephropathy is a serious kidney-related complication of type 1 diabetes and type 2 diabetes. It is also called diabetic kidney disease. About $25 \%$ of people with diabetes eventually develop kidney disease. The enzyme N-Acetyl- $\beta$-glucosaminidase (NAG) (EC: 3.2.1.30) is one of lysosomal acid hydrolases enzyme present in many body tissues with a high molecular weight $(\sim 140 \mathrm{kDa})$. It breaks chemical bonds of glycoside and amino sugars which form structural components in many tissues. Different pieces of cells need to be degraded and disposed of, including the cell membrane.
\end{abstract}

Method: By using ELISA kit, we measured urine and serum level of N-acetyl B-Glucosaminidase in 30 patients diabetes with Microalbuminuria: ACR: $<30 \mathrm{mg} / \mathrm{g}, 30$ patients diabetes with Macroalbuminuria: ACR $>30 \mathrm{mg} / \mathrm{g}$ with 30 healthy volunteers enlisted as normal controls.

Result: Urine concentration of NAG in macro and micro- groups was comparable $(13.23 \pm 1.04 \mathrm{ng} / \mathrm{mL}$ and $13.1 \pm 1.46 \mathrm{ng} / \mathrm{mL}$, respectively) with no significant difference, while both groups showed highly significant difference compared with normo- group $(5.15 \pm 2.11 \mathrm{ng} / \mathrm{mL})$ On the other hand, serum concentration of NAG in normo- micro- and macroabluminuria was $1.2 \pm 0.3 \mathrm{ng} / \mathrm{mL}, 2.5 \pm 0.58 \mathrm{ng} / \mathrm{mL}$ and $3.2 \pm 0.77 \mathrm{ng} / \mathrm{mL}$, respectively, with highly significant differences between the three groups.

Conclusion: N-Acetyl- $\beta$-Glucosaminidase: the present study, diabetic nephropathy was associated with elevated urinary and serum NAG values compared to a control group. This increase in NAG was parallel to the severity of renal involvement with a characteristic increasing trend was observed among the study groups regarding albuminuria.

Keywords: N-Acetyl- $\beta$-Glucosaminidase, diabetes mellitus, diabetic nephropathy, ELISA.

\section{Introduction}

Diabetes mellitus is a metabolic disorder or may be described as a diverse group of diseases with different causes. Worldwide, cancer ranks second and diabetes mellitus ranks twelfth in the list of causes of death.

\section{Corresponding Author:}

\section{Ahmed Mahdi Daham}

Post Graduate, Department of Chemistry and

Biochemistry, College of Medicine, AL-Nahrain

University, Iraq

e-mail: amdj1992@yahoo.com
(1), It is a chronic disease that affects approximately 26.9 percent of the U.S. population aged 65 years and older. 1.9 million diabetics are diagnosed each year, in addition to 7.0 million undiagnosed and untreated (2). The diagnosis of diabetic patients should be based on the following: $-\mathrm{HbA} 1 \mathrm{c}$ check with a limit of $\geq 6.5$ per cent. Fasting blood Glucose (FBG) $\geq 126 \mathrm{mg} / \mathrm{dL}$. or Glucose Tolerance Test; plasma glucose levels $\geq 200 \mathrm{mg}$ / dL after two hours of consumption of $75 \mathrm{~g}$ glucose $\mathrm{e}^{(3)}$. Untreated diabetic patients have chronic hyperglycemia, i.e. higher than normal blood glucose levels. The cause for this is either a low level of insulin (a polypeptide hormone secreted by the pancreatic beta cell), an unusual form of insulin, or both ${ }^{(4)}$. 
Diabetic nephropathy is a diabetes-complicated kidney disease. It can occur in people with type 2 diabetes, the most common form of diabetes caused by insulin resistance, or in people with type 1 diabetes, the type that begins earlier and results from reduced insulin production. The damage to the smallest blood vessels causes diabetic nephropathy ${ }^{(5)}$. Both kidneys start to leak proteins into the urine when small blood vessels begin to develop damage. The kidneys slowly lose their ability to remove waste products from the blood as damage to the blood vessels persists. ${ }^{(6)}$. The enzyme $\mathrm{N}$-Acetyl- $\beta$-glucosaminidase (NAG) (EC: 3.2 .1 .30 ) is one of lysosomal acid hydrolases enzyme present in many body tissues with a high molecular weight $(\sim 140$ $\mathrm{kDa}$ ). It breaks chemical bonds of glycoside and amino sugars which form structural components in many tissues. Different pieces of cells need to be degraded and disposed of, including the cell membrane. NAG present in the lysosomes of the proximal renal tubular cells at high concentrations. There are two main isoenzymes in the kidneys of humans. Isoenzyme-A is part of an intralysosomal compartment that is excreted by exocytosis in the urine. Isoenzyme-B is associated with the lysosomal membrane and excreted during tubular damage in urine. These two enzymes vary in their heat tolerance and in acid urine stability ${ }^{(7)}$. Because of its urine stability, its relatively large molecular mass that prevents glomerulus filtration and its involvement in high tubular lysosomal activity, elevation of urinary NAG activity has been taken as a marker for renal proximal tubular damage or more precisely loss of lysosomal integrity ${ }^{(8)}$.

The aim of the present study was to evaluate urine and serum level of in patients with Diabetic nephropathy, and compare this group with control healthy group as well as to investigate whether it can be used as a biomarkers for detection of diabetes.

\section{Materials and Method}

Study design case control study: The present study was executed during the term from August 2019 to November 2019. This study included 60 patients with diabetic nephropathy and 30 healthy controls. Group I consist of 30 patients with Microalbuminuria: ACR: $<30 \mathrm{mg} / \mathrm{g}$ Group II consist of 30 patients with Macroalbuminuria: ACR $>30 \mathrm{mg} / \mathrm{g}$ Groups III Consist of 30 of matched healthy subjects were used as control ACR $<20 \mathrm{mg} / \mathrm{g}$. All samples were collected from Medical City of Baghdad Teaching Hospital. About $6 \mathrm{ml}$ of blood samples were obtained from veins of patients having diabetic nephropathy and healthy control subjects. The 6 milliliters of blood were left for 15 minutes at room temperature. After coagulation, sera were separated by centrifugation at $3000 \mathrm{rpm}$. for 10 min. Sera were aspirated and divided into small aliquots for:-Immediate measurements of serum total protein, albumin, creatinine, blood urea, blood glucose, uric acid were done using appropriate method. The rest were stored at $-20 \mathrm{C}^{\circ}$ until assayed They were measured using enzyme-linked immunosorbent assay (ELISA) kits. Ten milliliters of urine were obtained from patients and healthy children, and then collected in the plane were centrifugation at $1000 \mathrm{x}$ g for approximately 10 minutes.

\section{Statistical Analysis:}

- In this study the data obtained was analyzed by Microsoft excel 2010 and SPSS version 23.

- The numerical data expressed as mean \pm SD.

- Student's t-test was used to calculate individual p-value, p-value $<0.05$ was considered significant.

For comparing mean of more than two groups the ANOVA was used.

\section{Result}

\section{Demographic and Clinical Characteristics of} the Study Population: The mean age of patients with normo-, micro- and macrobluminuria was $42.3 \pm 3.25$ years, $42.93 \pm 3.03$ years and $44.8 \pm 4.28$ years respectively with no significant difference. Similarly, there were no significant differences between the three groups in gender distribution, type of therapy and BMI. However, DM duration was significantly longer in macro $(8.77 \pm 4.2$ years) group than normo- group ( $5.63 \pm 4.96$ years). 
Table 1: Demographic and Clinical Characteristic of the patients

\begin{tabular}{|c|c|c|c|c|}
\hline Variables & Normo (30) & Micro (30) & Macro (30) & P-value \\
\hline Age, years (Mean \pm SD) & $42.3 \pm 3.25$ & $42.93 \pm 3.03$ & $44.8 \pm 4.28$ & 0.695 \\
\hline \multicolumn{5}{|l|}{ Sex, No(\%) } \\
\hline Male & $14(46.67 \%)$ & $15(50 \%)$ & $19(63.33 \%)$ & \multirow{2}{*}{0.392} \\
\hline Female & $16(53.33 \%)$ & $15(50 \%)$ & $11(36.67 \%)$ & \\
\hline Duration, years, $($ Mean \pm SD) & $5.63 \pm 4.96^{\mathrm{a}}$ & $7.67 \pm 4.36^{\mathrm{ab}}$ & $8.77 \pm 4.2^{\mathrm{b}}$ & 0.028 \\
\hline \multicolumn{5}{|l|}{ Therapy, No(\%) } \\
\hline Oral & $18(69.70 \%)$ & $22(73.53 \%)$ & $23(76.67 \%)$ & \multirow{2}{*}{0.329} \\
\hline Insulin & $12(30.30 \%)$ & $8(26.47 \%)$ & $7(23.33 \%)$ & \\
\hline $\mathrm{HbA} 1 \mathrm{c} \%($ Mean $\pm \mathrm{SD})$ & $7.32 \pm 1.12^{\mathrm{a}}$ & $9.18 \pm 1.79^{\mathrm{b}}$ & $10.22 \pm 1.72^{\mathrm{c}}$ & $<0.001$ \\
\hline BMI, $\mathrm{kg} / \mathrm{m}^{2},(\mathrm{Mean} \pm \mathrm{SD})$ & $26.78 \pm 1.71$ & $28.09 \pm 2.64$ & $27.84 \pm 3.6$ & 0.219 \\
\hline Glucose, $\mathrm{mg} / \mathrm{dl}(\mathrm{Mean} \pm \mathrm{SD})$ & $100.73 \pm 13.89^{\mathrm{a}}$ & $163.83 \pm 21.5^{\mathrm{b}}$ & $177.03 \pm 24.75^{\mathrm{c}}$ & $<0.001$ \\
\hline TSP Mean \pm SD) & $74.43 \pm 3.41^{\mathrm{a}}$ & $71.5 \pm 3.01^{b}$ & $70.73 \pm 4.27^{b}$ & $<0.001$ \\
\hline Albumin & $41.97 \pm 2.04^{\mathrm{a}}$ & $39.4 \pm 2.79^{b}$ & $39.7 \pm 3.14^{\mathrm{b}}$ & 0.001 \\
\hline
\end{tabular}

BMI: body mass index, SD: standard deviation

Different small letters indicate significant differences: Both HBA1c and FBS were significantly higher in macro group $(10.22 \pm 1.72 \%$ and $177.03 \pm 24.75$ $\mathrm{mg} / \mathrm{dL}$, respectively) than either normo- $(7.32 \pm 1.12 \%$ and $100.73 \pm 13.89 \mathrm{mg} / \mathrm{dL}$, respectively), or microgroup $(9.18 \pm 1.79 \%$ and $163.83 \pm 21.5$, respectively). In contrast, normo- group showed higher serum TSP and albumin $(74.43 \pm 3.41 \mathrm{mg} / \mathrm{dL}$ and $41.97 \pm 2.04 \mathrm{mg} /$ $\mathrm{dL}$, respectively) than either micro- $(71.5 \pm 3.01 \mathrm{mg} / \mathrm{dL}$ and $39.4 \pm 2.79 \mathrm{mg} / \mathrm{dL}$, respectively) or macro- group $(70.73 \pm 4.27 \mathrm{mg} / \mathrm{dL}$ and $39.7 \pm 3.14 \mathrm{mg} / \mathrm{dL}$, respectively) with highly significant difference (Table 1).
Urine and Serum Concentrations of NAG: Urine concentration of NAG in macro and micro- groups was comparable $(13.23 \pm 1.04 \mathrm{ng} / \mathrm{mL}$ and $13.1 \pm 1.46 \mathrm{ng} / \mathrm{mL}$, respectively) with no significant difference, while both groups showed highly significant difference compared with normo- group $(5.15 \pm 2.11 \mathrm{ng} / \mathrm{mL})$ as shown in figure 3-1. On the other hand, serum concentration of NAG in normo- micro- and macroabluminuria was $1.2 \pm 0.3 \mathrm{ng} / \mathrm{mL}, 2.5 \pm 0.58 \mathrm{ng} / \mathrm{mL}$ and $3.2 \pm 0.77 \mathrm{ng} / \mathrm{mL}$, respectively, with highly significant differences between the three groups (Figure 3-2).

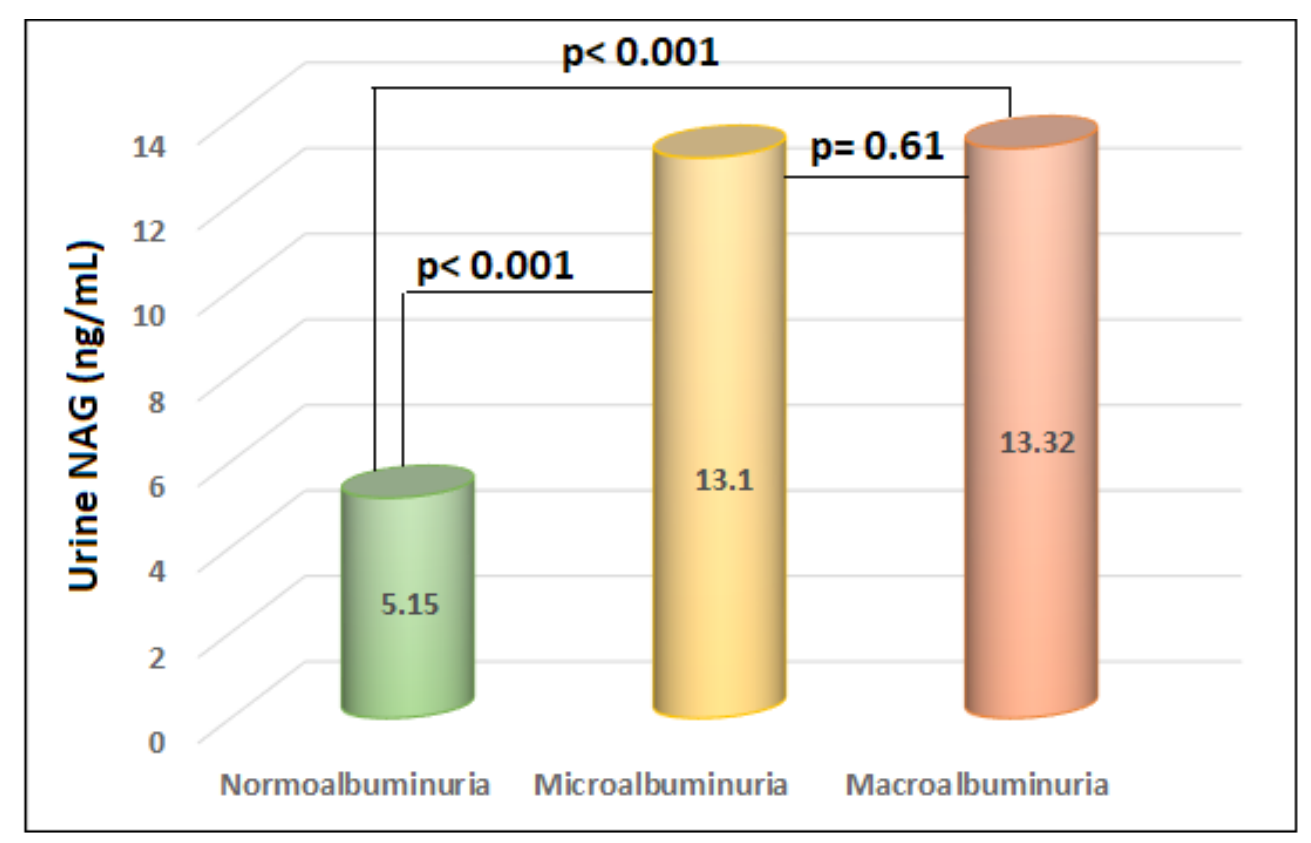

Figure 1: Urine concentration of NAG 


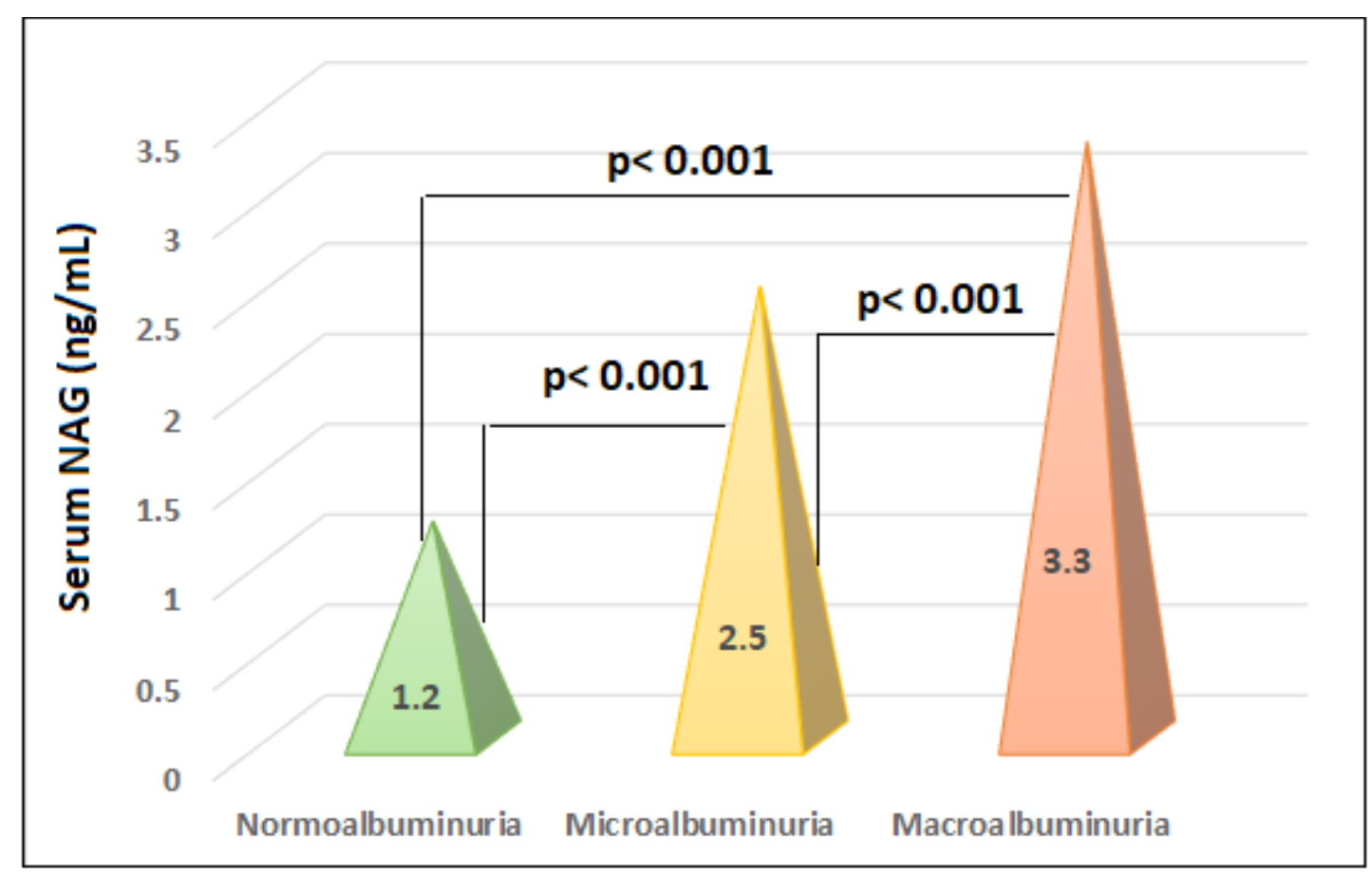

Figure 2: Serum concentration of NAG

\section{Discussion}

N-Acetyl- $\beta$-glucosaminidase : the present study, diabetic nephropathy was associated with elevated urinary and serum NAG values compared to a control group. This increase in NAG was parallel to the severity of renal involvement with a characteristic increasing trend was observed among the study groups regarding albuminuria. These results are in agreement with other studies ${ }^{(9)}$ that stated that changes in urinary and serum NAG activity can reflect the activity of the disease as well as the residual functional capacity of the kidney. Our results showed that even in the absence of any clinical evidence of microvascular complications, urinary NAG excretion was invariably elevated indicating that subclinical renal tubular dysfunction may exist before the occurrence of glomerular damage. Kuzniar et al. (2006) denoted that in proteinuric glomerular diseases the increased NAG excretion can occur even in absence of morphological evidence of tubular cell damage, probably reflecting increased lysosomal activity of these cells due to the increased uptake of filtered proteins. Physiologic increases in urinary NAG for metabolizing urinary glucose and the nephrotoxic effect of glycated end products on renal proximal tubules could be possible. NAG is an enzyme involved in carbohydrate metabolism. When the proximal tubules are exposed to high urinary glucose, NAG might be secreted more in the urine, depending on urinary glucose concentrations. In addition, the peptides derived from advanced glycation end products might have a potential nephrotoxic effect on the proximal tubule, thus contributing to the occurrence of proximal tubule injury

\section{Conclusion}

The cutoff value of urine and serum NAG high levels of NAG between groups compared with controls. This difference is useful for distinguishing between study groups.

Ethical Clearance: The Research Ethical Committee at scientific research by ethical approval of both $\mathrm{MOH}$ and MOHSER in Iraq.

\section{Conflict of Interest: None}

Funding: Self-funding

\section{References}

1. Kripal K. Prevalence and incidence of periodontal diseases in diabetes mellitus patients. EC Dental Science. 2017;9:173-81.

2. Keum N, Ha KH, Bao Y, Chung MJ, Kim HC, Giovannucci EL. Long-term patterns of fasting blood glucose levels and pancreatic cancer 
incidence. Cancer Causes \& Control. 2018 Jan 1;29(1):135-42.

3. Thrailkill KM, Nyman JS, Bunn RC, Uppuganti S, Thompson KL, Lumpkin Jr CK, Kalaitzoglou E, Fowlkes JL. The impact of SGLT2 inhibitors, compared with insulin, on diabetic bone disease in a mouse model of type 1 diabetes. Bone. 2017 Jan 1;94:141-51.

4. Bramham, K.,, July. Diabetic nephropathy and pregnancy. In Seminars in nephrology, 2017, pp. 362-369

5. Gnudi L, Coward RJ, Long DA. Diabetic nephropathy: perspective on novel molecular mechanisms. Trends in Endocrinology \& Metabolism. 2016 Nov 1;27(11):820-30.

6. Kopf S, Oikonomou D, Zdunek D, von Eynatten M, Hess G, Nawroth PP, Bierhaus A, Humpert
PM. Urinary n-acetyl-beta-d-glucosaminidase excretion: An indicator of neuropathy in type 2 diabetes. Experimental and Clinical Endocrinology \& Diabetes. 2013 Nov;121(10):601-6.

7. Ristikankare A. Acute kidney injury in cardiac surgery 2017.

8. Sajjadian, S.M., Ahmed, S., Al Baki, M.A. and Kim, Y.,. Prostaglandin D2 synthase and its functional association with immune and reproductive processes in a lepidopteran insect, Spodoptera exigua. General and Comparative Endocrinology,2020 287, p.113352.

9. Zhang, X., Zhou, H. and Li, Y.,. Combined detection of urinary micro albumin, $\alpha 1$-microglobulin and $\mathrm{N}$-acetyl- $\beta$-D-glucosaminidase in the early diagnosis of diabetic nephropathy. Pakistan journal of medical sciences, 2017, 33(6), p.1324. 